\title{
THEORETICAL FRAMEWORK, FALSAFAH DAN PRINSIP- PRINSIP DASAR ILMU MANAJEMEN PENDIDIKAN
}

\author{
Nur Khoiri \\ Universitas Islam Negeri Walisongo Semarang \\ nurkhoiri@walisongo.ac.id
}

\begin{abstract}
ABSTRAK
Tulisan ini merupakan refleksi pemberdayaan bagi pengelola pendidikan dalam menerapkan kebijakan kurikulum pendidikan bagi anak inklusi. Tantangan dan hambatan dalam implementasi pendidikan inklusi menjadi tanggung jawab bersama yaitu pemerintah, dinas pendidikan, kepala sekolah, guru, orang tua, dan masyarakat. Karena itu diperlukan pengelolaan yang komprehensif mulai dari kurikulum, pendidik, tenaga kependidikan, dan sarana prasarana sekolah. Kurikulum di sekolah inklusi harus memperhatikan kebutuhan dasar anak yang beraneka ragam, tidak bisa disamakan kemampuan anak regular dengan anak berkebutuhan khusus sehingga perencanaan pembelajaran yang disusun oleh guru harus dapat mengakomodir hal tersebut.
\end{abstract}

Kata Kunci: Manajemen Pendidikan Islam, Teori, Falsafah dan Prinsip.

\begin{abstract}
This paper is reflection of empowerment for the provider of education in implementing the policy of education curriculum for inclution child. Challenges and obstacles in the implementation of education inclution becomes a shared responbility, namely the government, the department of education, school principal, teachers, parents, and community. Therefore, the required comprehensive management starts from curriculum, educators, educational personel, infrastructure and facilities of the school. The curriculum at the school inclution should pay attention to the basic needs of the child that a multi-faceted, it can't be equated with a regular child's ability children in need special so planning study compiled by the teacher must be able to accommodate it such.
\end{abstract}

Keywords: Islamic education management, theory, philosophy and principle 


\section{PENDAHULUAN}

Lembaga pendidikan merupakan suatu wadah lembaga yang mengantarkan seseorang pada alur berpikir yang teratur dan sistematis. Sebuah lembaga pendidikan pada pelaksanaannya seringkali dihadapkan pada problem-problem sistem pembelajaran yang ditemukan solusi alternatifnya, mulai dari penyiapan sarana dan prasarana, materi, tujuan bahkan sampai pada penyiapan proses. Guru sebagai pelaksana pendidikan memegang peranan vital untuk mensukseskan program lembaga pendidikan. Terkait dengan hal tersebut Mustaqim pada setiap kesempatan menegaskan perlunya guru terampil untuk mengajar, yang secara global meliputi manajemen perencanaan, pelaksanaan, dan evaluasi (Mustaqim, n.d.).

Perkembangan lembaga pendidikan sebagai lembaga yang bergerak di bidang non-profit oriented, memaksa pelaksana pendidikan menggunakan teori-teori yang sebelumnya sudah berkembang pada dunia ekonomi. Maka tidak heran ketika kita mendengar adanya teori manajemen pendidikan, yang pada dasarnya itu diambil dari teori-teori manajemen pada dunia bisnis. Bukan berarti setelah meminjam teori manajemen ekonomi sebuah lembaga pendidikan menjadi komersial, tetapi sematamata hanya digunakan sebagai landasan yang sistematik untuk mengelola sebuah lembaga pendidikan.

Manajemen dalam pendidikan dapat diartikan sebagai aktivitas memadukan sumber-sumber pendidikan agar terpusat dalam usaha mencapai tujuan pendidikan yang telah ditentukan sebelumnya. Manajemen pendidikan merupakan suatu proses untuk mengkoordinasikan berbagai sumber daya pendidikan seperti guru, sarana dan prasarana pendidikan untuk mencapai tujuan dan sasaran pendidikan, yaitu mencerdaskan kehidupan bangsa dan mengembangkan manusia seutuhnya, yaitu manusia yang beriman dan bertaqwa terhadap Tuhan Yang Maha Esa dan berbudi pekerti luhur, memiliki pengetahuan dan keterampilan, kesehatan jasmani dan rohani, kepribadian yang mantap dan mandiri serta rasa tanggung jawab kemasyarakatan dan kebangsaan.

Manajemen pendidikan sebagai suatu disiplin ilmu memainkan peranan yang amat penting dalam mewujudkan sistem pendidikan yang bermutu dan berkelanjutan. Manajemen sistem pendidikan amat penting karena proses penataan sumber daya pendidikan (pengelolaan tenaga kependidikan, kurikulum dan pembelajaran, keuangan, sarana dan prasarana pendidikan, serta keterlibatan secara terpadu dan 
simultan antara pemerintah, sekolah dan masyarakat) perlu dikelola secara profesional.

\section{METODE PENELITIAN}

Metode yang digunakan dalam penelitian ini adalah penelitian kulitatif. Jenis penelitian yang digunakan yaitu penelitian deskriptif kualitatif. Suharsimi Arikunto dalam buku Manajemen Penelitian (2003: 234) menjelaskan Penelitian deskriptif kualitatif tidak dimaksudkan untuk menguji hipotesis tertentu, tetapi hanya menggambarkan apa adanya tentang suatu variabel, gejala atau keadaan.

Penelitian ini adalah Penelitian Literatur juga sering disebut dengan istilah penelitian Kepustakaan (Library Research). Data penelitian diambil dari data primer berupa buku-buku tentang manajemen pendidikan. Metode analisis yang dipakai adalah metode deskriptif, dengan teknik analisi isi (content analysis), Teknik analisis ini adalah mengungkapkan konsep-konsep dan gagasan-gagasan yang terdapat pada data primer, kemudian di analisis dengan didukung data-data sekunder, untuk selanjutnya melalui analisis ini, data-data tersebut akan ditarik kesimpulan, Fokus penelitian ini terletak pada manajemen pendidikan.

\section{PEMBAHASAN}

\section{A. Kerangka Teori (Theoretical Framework) IImu Manajemen}

Teori pada bidang manajemen mempunyai peranan yang sama dengan teori yang ada pada ilmu fisika, kimia, atau biologi, yaitu berfungsi untuk menjelaskan dan panduan pada penelitian. Berdasarkan konsep tersebut teori sebagai bagian dari ilmu berfungsi untuk menjelaskan (explanation), memprediksi atau meramalakan (prediction), dan mengendalikan (control).

Pembahasan tentang teori manajemen, ada kaitan erat antara organisasi, administrasi, dan manajemen, ketiganya seperti tiga sisi pada segitiga. Menurut Made Pidarta, organisasi adalah sekumpulan orang dengan ikatan tertentu yang merupakan wadah untuk mencapai cita-cita, mula-mula mereka mengintegrasikan sumbersumber materi maupun sikap para anggota yang dikenal sebagai manajemen dan 
akhirnya barulah mereka melaksanakan kegiatan-kegiatan untuk mencapai cita-cita tersebut, baik manajemen maupun melaksanakan kegiatan itu disebut administrasi (Pidarta, 2004). Luwis R. Benston, mendefinisikan administrasi sebagai cara kerja pemerintahan dengan fungsi merencanakan, mengorganisasi, dan memimpin (Luwis R. Benston, 1972).

Adapun pengertian manajemen berasal dari bahasa Belanda "administratie" yang berarti tata usaha. Istilah lain manajemen berasal dari bahasa Inggris "management" sebagai "the management of exeutive affairs" suatu pengertian dalam lingkup yang lebih luas dari sekedar pekerjaan tulis menulis atau tata usaha, tetapi suatu rangkaian segala kegiatan yang menunjuk pada usaha kerjasama antara dua orang atau lebih untuk mencapai suatu tujuan yang telah ditetapkan (Arikunto \& Lia Yuliana, 2012).

Menurut Parker manajemen ialah seni melaksanakan pekerjaan melalui orangorang (the art of getting things done through people). Dalam bukunya Made Pidarta manajemen adalah pusat administrasi, administrasi berawal dan berakhir pada manajemen. Manajemen adalah inti administrasi, karena manajmen merupakan bagian utama administrasi, dengan tugas-tugasnya yang paling menentukan administrasi. Inilah yang merupakan hakikat manajemen, suatu aktivitas yang menjadi pusat administrasi, pusat atau inti kerjasama antar anggota organisasi untuk mencapai tujuan yang telah ditetapkan sebelumnya (Pidarta, 2004).

Sulistyorini dalam bukunya Manajemen Pendidikan Islam mengemukakan arti manajemen sebagai berikut kegiatan seseorang dalam mengatur organisasi, lembaga atau sekolah yang bersifat manusia maupun non manusia, sehingga tujuan organisasi, lembaga atau sekolah dapat tercapai secara efektif dan efisien (Sulistyorini, 2009). Sukamto Reksohadiprodjo dalam bukunya Dasar-Dasar Manajemen mengartikan manajemen sebagai berikut: manajemen bisa berarti fungsi, peranan maupun keterampilan manajemen sebagai fungsi meliputi usaha perencanaan, pengorganisasian, pengarahan, pengkoordinasian dan pengawasan. Manajemen sebagai peranan adalah antar pribadi pemberi informasi dan pengambil keputusan. Manajemen dapat pula berarti pengembangan keterampilan, yaitu teknis, manusiawi dan konseptual (Sukamto Reksohadiprodjo, 1996).

Teori manajemen adalah sebuah kumpulan ide-ide yang ditetapkan aturan umum tentang bagaimana mengelola sebuah organisasi yang merupakan suatu 
prinsip yang disusun melalui proses perencanaan, pengerganisasian, pengarahan, dan pengawasan dalam organisasi untuk mencapai tujuan yang telah ditetapkan.

Teori di bidang manajemen pendidikan secara spesifik berguna untuk menentukan cara atau strategi agar pendidikan dapat dikelola secara efektif dan efisien. Dengan teori, dapat ditemukan cara yang tepat untuk mengelola sumber daya, cara termudah mengerjakan pekerjaan, dana yang termurah membiayai pekerjaan, waktu yang tersingkat untuk melaksanakan pekerjaan, alat yang tepat untuk memperingan beban dan memperpendek jarak melaksanakan pekerjaan.

Konteks pendidikan, manajemen itu dapat diartikan sebagai aktivitas memadukan sumber-sumber pendidikan agar terpusat pada dunia usaha mencapai tujuan pendidikan yang telah ditentukan sebelumnya. Dipilih manajemen sebagai aktivitas agar kepala sekolah berperan sebagai administrator untuk mengemban misi atasan, sebagai manager untuk memadukan sumber-sumber pendidikan dan sebagai supervisor untuk membina guru-guru pada proses pembelajaran (Sondang P. Siagian, 1985).

\section{B. Landasan Filososfis Teori Manajemen}

Manusia sebagai pencetus dan pelaksana teori manajemen, memiliki hakikat kemanusiaan yang disebut kemandirian (individualitas) berupa kesadaran akan identitas diri yang berbeda satu dengan lainnya, dan juga berbeda dari binatang. Kesadaran itu dimiliki manusia sebagai individu karena kehadiran individu yang lain, dengan kelebihan dan kekurangan masing-masing (Imam al-Mawardi, 1955). Setiap individu hanya akan merasakan kehidupannya berarti dan bermakna, ketika mereka saling berhubungan antara satu dengan yang lain.

Hakikat manusia yang mendorongnya untuk hidup berkelompok atau bermasyarakat itu, menurut Hadari Nawawi secara khusus diwujudkannya dengan membentuk berbagai organisasi. Perbedaan organisasi yang dibentuk manusia itu didasari oleh kodratnya sebagai makhluk yang memiliki kebutuhan yang sama, yang kerap kali sulit dipenuhi melalui usaha secara perorangan, dan sebaliknya akan lebih mudah dipenuhinya jika diusahakan secara bersama-sama (Hadari Nawawi, 2005).

Perilaku manusia pada sebuah organisasi memiliki ragam variabel yang mempengaruhinya, baik dari individu, variabel lingkungan atau organisasi. Hal ini membawa implikasi praktik manajerial yang efektif untuk mengakui perbedaanperbedaan perilaku pada individu, dan mungkin dipertimbangkan ketika melakukan pekerjaan atau tugas. Mengapa individu melakukan tindakan tertentu, kebutuhan 
apakah yang ingin mereka penuhi. Perilaku individu inilah yang nantinya diakui dan merupakan faktor penting untuk meningkatkan produktivitas individu dan kelompok pada organisasi, yang berpengaruh terhadap tujuan organisasi. Mewujudkan tujuan tersebut, Malayu Hasibuan menyarankan agar pemimpin organisasi/manajer dalam memimpin para bawahannya harus mampu memberikan dorongan, pengarahan, bimbingan, penyuluhan, pengendalian, keteladanan, ketegasan, kedisiplinan dan kejujuran, agar para bawahan mau bekerja sama dan bekerja efektif untuk mewujudkan tujuan yang diinginkan (Malayu S.P. Hasibuan, 2008).

Teori manajemen secara filosofis mendasari sebuah kepemimpinan agar mampu membangun kehidupan organisasi dengan mengembangkan budaya yang disebut nilai-nilai ekselensi/keunggulan yang dalam istilah Sudarwan Danim disebut value of exellence. Organisasi manajemen memerlukan pimpinan/manajer yang mengerti benar perkembangan teori-teori manajemen agar pemimpin atau manajer tersebut memiliki visi yang bijaksana dan mampu mengilhami staf/pekerja dan semua komunitas organisasi (Danim \& Suparno, 2009).

\section{Teori-Teori Manajemen dalam Kanvas Peradaban}

Teori-teori manajemen dalam lintas sejarah dapat dikelompokkan menjadi beberapa kelompok, yaitu :

\section{Teori Manajemen Kuno}

Sebelum manajemen dijadikan teori secara terstruktur, pada zaman kuno sudah muncul teori-teori manajemen sebagaimana dimaksud, yang disebut teori manajemen kuno. Sampai dengan tingkat tertentu, manajemen telah dipraktikkan oleh masyarakat kuno (Muhammad Ja'far Nashir, 2006). Sebagai contoh, bangsa Mesir bisa membuat piramida, kerajaan Hindu di Jawa sudah bisa membuat candi yang menjadi bagian keajaiban dunia, mengapa ? karena bangunannya yang cukup kompleks yang hanya bisa diselesaikan dengan koordinasi yang baik dan matang. Kekaisaran Romawi mengembangkan struktur organisasi yang jelas, dan sangat membantu komunikasi dan pengendalian.

\section{Teori Manajemen Klasik}

Teori manajemen klasik berkembang sejak tahun 1980-an. Aliran ini menggunakan pemikiran deduktif dalam membahas konsep desain organisasi manajemen dan deskripsi apa yang harus diperbuat tiap orang dalam organisasi manajemen (Hamalik, 2012). Tokoh-tokoh penting teori manajemen klasik ini antara lain: 


\section{a. Robert Owen (1771-1858)}

Owen memiliki simpulan bahwa manajer harus menjadi pembaru (reformer). Owen melihat peranan pekerja sebagai faktor yang cukup penting sebagai aset perusahaan. Pekerja bukan saja merupakan input, tetapi merupakan sumber daya perusahaan yang signifikan. Owen juga memperbaiki kondisi pekerjanya, dengan mendirikan perumahan sebagai tempat tinggal yang lebih baik bagi para pekerjanya. Owen juga mendirikan toko, agar pekerjanya tidak kesusahan dan dapat membeli kebutuhan hidup dengan harga yang murah dan terjangkau. Owen juga mengurangi jam kerja dar 15 jam menjadi 10,5 jam, dan menolak pekerja di bawah umur 10 tahun (Tunggal, 1993).

\section{b. Charles Babbage (1792-1871)}

Babbage merupakan Professor Matematika di Inggris. Dengan metode kuantitatifnya Babbage percaya bahwa : 1) Prinsip-prinsip ilmiah dapat diterapkan untuk meningkatkan efisiensi produksi. Produksi naik, biaya operasi turun; 2) Pembagian kerja (division of labor); dengan ini keja atau operasi perusahaannya bisa dianalisis secara terpisah. Dengan cara seperti ini pula training bisa dilakukan dengan lebih mudah; dan 3) Dengan melakukan pekerjaan yang sama secara berulang-ulang, pekerja akan semakin terampil dan hal itu berarti semakin efisien.

\section{Teori Manajemen Organisasi}

Teori manajemen organisasi berpendapat bahwa semua manajer dalam setiap organisasi sangat dipengaruhi oleh variabel-variabel organisasi dan manusia. Tugas manajer adalah bagaimana mengintegrasikan variabel-variabel tersebut (Gomes, 2003), dan untuk itu seorang manajer memerlukan suatu mekanisme guna melakukan penyesuaian-penyesuaian yang diperlukan. Teori tentang manajemen organisasi dikemukakan oleh tokoh-tokoh seperti :

\section{a. Henry Fayol (1841-1925)}

Henry Fayol merupakan industrialis Prancis, ia disebut bapak aliran manajemen klasik (Darmono, 2001) karena upaya mensistematir studi manajerial. Menurut Fayol, praktik manajemen dapat dikelompokkan menjadi beberapa pola yang dapat diidentifikasi dan dianalisis. Selanjutnya analisis tersebut dapat dipelajari oleh manajer lain atau calon manajer. Fayol adalah orang yang pertama mengelompokkan kegiatan manajerial menjadi empat fungsi manajemen, yaitu : a) Perencanaan; b) Pengorganisasian; c) 
Pengarahan; dan d) Pengendalian. Fayol percaya bahwa manajer bukan dilahirkan tetapi diajarkan. Manajemen bisa dipelajari oleh seseorang dan dipraktikkan secara efektif apabila prinsip-prinsip dasarnya dipahami.

Fayol menekankan adanya kebutuhan terhadap pelatihan pada bidang manajemen, baik pelatihan formal dan tidak formal. Fayol juga menyatakan perlu adanya kualitas dari manajer (pemimpin) baik secara pisik, mental, moral, pendidikan, dan hal-hal yang bersifat teknis. Suatu manajemen perlu perlu menekankan pada prinsip keluwesan, dan pada waktu yang sama juga harus menekankan pada prinsip-prinsip manajemen secara umum (Darmono, 2001).

\section{b. Max Weber (1864-1920)}

Max Weber adalah seorang ahli sosiolog Jerman yang mengembangkan teori birokrasi . Menurutnya, suatu organisasi yang terdiri dari ribuan anggota membutuhkan aturan jelas untuk anggota organisasi tersebut. Organisasi yang ideal adalah birokrasi dimana aktivitas dan tujuan diturunkan secara rasional dan pembagian kerja disebut dengan jelas. Birokrasi didasarkan pada aturan yang rasional yang dapat dipakai untuk mendesain struktur organisasi yang jelas (Fatah, 2009). Konsep birokrasi Weber berlainan dengan pengertian birokrasi populer, orang cenderung mengartikan kata birokrasi dengan konotasi negatif, yaitu organisasi yang lamban, tidak responsif terhadap perubahan.

\section{c. Mary Parker Follet (1868-1933)}

Mary Parker Follet percaya bahwa seseorang akan menjadi manusia sepenuhnya apabila manusia menjadi anggota suatu kelompok. Konsekuensinya, Mary Parker Follet percaya bahwa manajemen dan pekerja mempunyai kepentingan yang sama dalam organisasi, karena manusia menjadi anggota organisasi yang sama. Selanjutnya Follet mengembangkan model perilaku pengendalian organisasi di mana seseorang dikendalikan oleh tiga hal, yaitu ; a) Pengendalian diri (dari orang tersebut); b) Pengendalian kelompok (dari kelompok); dan c) Pengendalian bersama (dari orang tersebut dan dari kelompok). Menurut Follet, seorang manajer bertugas mengatur dan mengarahkan orang lain untuk mencapai tujuan organisasi (Danim \& Suparno, 2009).

\section{d. Chester I Bernard (1886-1961)}

Bernard mengembangkan teori organisasi, menurutnya orang yang datang ke organisasi formal (seperti perusahaan) karena ingin mencapai tujuan 
yang tidak dapat dicapai sendiri. Pada waktu mereka berusaha mencapai tujuan organisasi, mereka juga akan berusaha mencapai tujuannya sendiri. Organisasi bisa berjalan dengan efektif apabila keseimbangan tujuan organisasi dengan tujuan anggotanya dapar terjaga (Fatah, 2009). Bernard percaya keseimbangan tujuan organisasi dengan tujuan individu dapat terjaga apabila manajer mengerti konsep wilayah perencanaan (zone of acceptance), di mana pekerja akan menerima instruksi atasannya tanpa mempertanyakan otoritas manajemen.

\section{e. Mazhab Perilaku (Behavioral Scince)}

Mazhab perilaku memandang organisasi pada hakikatnya adalah orang. Mazhab perilaku ini memandang mazhab klasik kurang lengkap karena mampu mewujudkan efisiensi produksi yang sempurna dan keharmonisan di tempat kerja. Manusia di dalam organisasi tidak selalu dapat dengan mudah diramalkan tingkah lakunya karena sering juga tidak rasional. Karena itu para manajer perlu dibantu untuk menghadapi manusia, antara lain dengan sosiologi.

\section{f. Mazhab Kuantitatif (The Quantitatif School)}

Mazhab kuantitatif terdiri dari Operation Research dan Management Science, di mana berkumpul para sarjana Matematika, Fisika, dan sarjana eksak lainnya untuk memecahkan masalah-masalah yang lebih ruwet. Mazhab ini lebih diformilkan menjadi mazhab IImu Manajemen (Management Science School). Mazhab ini mengembangkan model-model untuk memecahkan masalahmasalah menejemen yang kompleks. Dengan memenuhi berbagai faktor sebagai variabel yang saling berkaitan, maka dengan bantuan komputer, model itu dapat memberi pemecahan masalah yang lebih berdasar rasional kepada para manajer ketika membuat keputusan-keputusannya (Muhammad Ja'far Nashir, 2006).

Teknik-teknik ilmu manajemen mazhab kuantitatif ini banyak membantu para manajer organisasi yang bener-benar pada berbagai kegiatan penting, seperti pada penganggaran model dan manajemen arus dana, penjadwalan produksi, strategi pengembangan produksi, perencanaan sumber daya manusia, penanggulangan logistik, dan penjadwalan pesawat terbang.

\section{g. Pendekatan Sistem (The System Approach)}

Sistem dapat diartikan gabungan sub-sub sistem yang saling berkaitan. Organisasi sebagai suatu sistem akan dipandang secara keseluruhan, terdiri dari bagian-bagian yang berkaitan (sub-sistem), dan sistem/organisasi tersebut akan 
berinteraksi dengan lingkungan. Pada proses selanjutnya pendekatan inilah yang selama ini digunakan pada sistem manajemen pendidikan di Indonesia. Sebelum munculnya sistem pendekatan yang baru.

\section{h. Pendekatan Hubungan Manusia Baru (Neo-Human Relation)}

Pendekatan ini berusaha mengintegrasikan sisi positip manusia dan manajemen ilmiah. Pendekatan ini melihat bahwa manusia merupakan makhluk yang emosional, intuitif, dan kreatif. Dengan memahami kedudukan manusia tersebut, prinsip manajemen dapat dikembangkan lebih lanjut. Tokoh yang dapat disebut mewakili aliran ini adalah W. Edward Demin, yang mengembangkan prinsip-prinsip manajemen seperti Fayol yang berfokus pada kualitas kerja dan hubungan antar karyawan.

Temuan dari hasil penelitian tokoh-tokoh manajemen aliran Human Realition ini menunjukkan ada faktor tertentu yang berpengaruh pada sikap dan perilaku dan produktivitas para pekerja. Temuan hasil penelitian mereka menunjukkan bahwa sikap dan perilaku positip serta produktivitas para karyawan tidak terlalu dipengaruhi oleh fasilitas dan kondisi kerja, melainkan oleh perhatian yang diberikan oleh manajemen pada karyawan. Temuan kedua penelitian para tokoh di atas adalah bahwa perilaku seorang pekerja sangat ditentukan dan terikat pada norma-norma kelompok kerja di mana seseorang menjadi kelompok menjadi anggota (Siagian, 2008).

\section{i. Pendekatan Situasional (The Contingency Approach)}

Pendekatan ini menganggap bahwa efektivitas manajemen tergantung pada situasi yang melatarbelakanginya. Prinsip manajemen yang sukses pada situasi tertentu, belum tentu efektif apabila digunakan pada situasi yang lainnya. Tugas manajer ialah mencari teknik yang paling baik untuk mencapai tujuan organisasi, dengan melihat situasi, kondisi, dan waktu tertentu. Pendekatan situasional memberikan resep praktis terhadap persoalan manajemen. Tidak mengherankan jika pendekatan ini dikembangkan manajer, konsultan, atau peneliti yang banyak berkecimpung dengan dunia nyata. Pendekatan ini menyadarkan manajer bahwa kompleksitas situasi manajerial, membuat manajer fleksibel atau sensitif ketika memilih teknik-teknik manajemen yang terbaik berdasarkan situasi ganda (Muhammad Ja'far Nashir, 2006).

\section{Falsafah Manajemen Pendidikan}


Falsafah adalah ilmu pengetahuan yang komprehensif yang berusaha memahami persoalan-persoalan yang timbul di dalam keseluruhan ruang lingkup pengalaman manusia. Dengan demikian falsafah dibutuhkan manusia dalam upaya menjawab pertanyaan- pertanyaan yang timbul dalam berbagai lapangan kehidupan manusia, termasuk masalah kehidupan dalam bidang pendidikan. Jawaban hasil pemikiran falsafah bersifat sistematis, integral, menyeluruh dan mendasar. Falsafah dalam mencari jawaban dilakukan dengan cara ilmiah, objektif, memberikan pertanggungjawaban dengan berdasarkan pada akal budi manusia, demikian halnya untuk menjawab persoalan-persoalan manusia dalam bidang pendidikan. Pada prinsipnya falsafah menempatkan sesuatu berdasarkan kemampuan daya nalar manusia. Kebenaran dalam konteks falsafah adalah kebenaran yang tergantung sepenuhnya pada kemampuan daya nalar manusia. Kemampuan berpikir atau bernalar merupakan satu bentuk kegiatan akal manusia melalui pengetahuan yang diterima melalui panca indera, diolah dan ditujukan untuk mencapai suatu kebenaran.

Filsafat bersifat menyeluruh, mendasar, dan spekulatif. Dengan kata lain cakupan filsafat hanyalah mengenai hal-hal yang bersifat umum. Hal-hal yang bersifat khusus menjadi kajian ilmu termasuk ilmu manajemen. Manajemen mengandung tiga pengertian yaitu:

\section{Manajemen sebagai suatu proses}

Manajemen adalah suatu proses tertentu yang terdiri atas perencanaan, pengorganisasian, penyusunan pergerakan dan pengawasan yang dilakukan untuk menentukan dalam mencapai tujuan yang telah ditetapkan dengan menggunakan manusia atau orang-orang dan sumber daya lainnya (Purwanto, 1991). Selanjutnya manajemen adalah proses perencanaan, pengorganisasian, pemimpin dan pengendalian upaya anggota organisasi dan penggunaan semua sumber daya organisasi untuk mencapai tujuan yang telah ditetapkan secara efektif dan efisien (M, 2003). Dari dua definisi tersebut dapat disimpulkan bahwa ada tiga pokok penting dalam defisi tersebut yaitu, pertama adanya tujuan yang ingin dicapai, kedua tujuan yang dicapai dengan mempergunakan kegiatan orang lain, dan ketiga kegiatan orang lain itu harus dibimbing dan diawasi.

\section{Manajemen sebagai kolektivitas}

Orang-orang yang melakukan aktivitas manajemen. Jadi setiap orang yang melakukan aktivitas manajemen dalam suatu badan tertentu disebut manajemen. Dalam arti tunggal disebut manajer. Manajer adalah pejabat yang bertanggung 
jawab atas terselenggaranya aktivitas-aktivitas manajemen agar tujuan unit pimpinannya tercapai dengan menggunakan bantuan orang lain.

\section{Manajemen sebagai suatu seni dan ilmu,}

Manajemen sebagai seni berfungsi untuk mencapai tujuan yang nyata mendatangkan hasil atau manfaat, sedangkan manajemen sebagai ilmu berfungsi menerangkan fenomena-fenomena, kejadian-kejadian, dan kedaan-keadaan. Banyak pakar manajemen yang mengemukakan pendapat mereka tentang pengertian manajemen. Namun dalam perspektif lebih luas, manajemen adalah suatu proses pengaturan dan pemamfaatan sumber daya yang dimiliki organisasi melalui kerjasama para anggota untuk mencapai tujuan organisasi secara efektif dan ofisien. Dengan kata lain, organisasi adalah wadah bagi operasionalisasi manajemen.

Secara sederhana dapat dipahami bahwa manajemen pendidikan ialah suatu usaha penerapan prinsip-prinsip dan teori manajemen dalam aktivitas pendidikan pada lembaga-lembaga pendidikan untuk mencapai tujuan pendidikan secara efektif dan efisien. Berarti pangkal tolak kerangka kerja manajemen pendidikan ialah prinsip-prinsip dan teori manajemen umum yang diaplikasikan untuk mengelola kegiatan pendidikan pada suatu organisasi pendidikan formal.

\section{E. Prinsip-prinsip Dasar}

\section{Prinsip-Prinsip Manajemen}

Secara sederhana prinsip-prinsip manajemen berarti dasar-dasar dan nilai yang menjadi inti dari keberhasilan sebuah manajemen. Atau juga dapat disebut sebagai teori rancangan (design teory) yang dapat digunakan oleh seorang perancang organisasi seperti halnya seorang insinyur menggunakan teori dalam hal mendesain sebuah mesin (Winardi, 2004).

Pentingnya prinsip-prinsip dasar dalam praktik manajemen antara lain: 1) menentukan cara/metode kerja; 2) pemilihan pekerja dan pengembangan keahliannya; 3) pemilihan prosedur kerja; 4) menentukan batas-batas tugas; 5) mempersiapkan dan membuat spesifikasi tugas; 6) melakukan pendidikan dan latihan; 7) menentukan sistem dan besarnya imbalan. Semuanya itu dimaksudkan untuk meningkatkan efektivitas, efisiensi, dan produktivitas kerja.

Dalam kaitannya dengan prinsip-prinsip dasar manajemen, Henri Fayol (1841-1925), seorang ahli teori manajemen dan administrasi yang berasal dari Perancis memperkenalkan 14 prinsip manajemen dalam bukunya yang berjudul 
"Administration Industrielle et Generale". Ke-14 prinsip dasar tersebut dijadikan patokan dalam praktik manajerial dalam melakukan manajemen (Fatah, 2009). Prinsip-prinsip manajemen adalah dasar-dasar dan nilai yang menjadi inti dari keberhasilan sebuah manajemen. Prinsip-prinsip dalam manajemen yaitu :

\section{a. Manajemen Berdasarkan Sasaran (MBS)}

MBS secara istilah merupakan terjemahan dari school based management. Istilah ini muncul di Amerika Serikat ketika masyarakat mulai mempertanyakan relevansi pendidikan dengan tuntutan dan perkembangan masyarakat setempat (Duhou, 2004). Istilah MBS (Manajemen Berdasarkan Sasaran) pertama kali dipopulerkan sebagai suatu pendekatan terhadap perencanaan oleh Peter Drucker (1954). MBS merupakan paradigma baru pendidikan, yang memberikan otonomi luas pada tingkat sekolah (pelibatan masyarakat) dalam kerangka kebijakan pendidikan nasional.

MBS diletakkan pada optimalisasi semua pihak yang terlibat di sekolah dalam memajukan sekolah tersebut. Secara konseptual MBS dapat didefinisikan sebagai proses manajemen sekolah yang diarahkan pada peningkatan mutu pendidikan, yang mana secara otonomi direncanakan, diorganisasikan, dilaksanakan, dan dievaluasi sendiri oleh sekolah sesuai dengan kebutuhan sekolah dengan melibatkan semua stakeholder sekolah. Sesuai dengan konsep tersebut, MBS pada hakikatnya merupakan pemberian otonomi kepada sekolah untuk secara aktif serta mandiri mengembangkan dan melakukan berbagai program peningkatan mutu pendidikan sesuai dengan kebutuhan sekolah itu sendiri.

\section{b. Manajemen Berdasarkan Orang ( MBO )}

Manajemen berdasarkan orang merupakan suatu konsep manajemen modern yang mengkaji keterkaitan dimensi perilaku, komponen sistem dalam kaitannya dengan perubahan dan pengembangan organisasi. Perubahan perilaku dan perubahan organisasi merupakan bagian esensial dari manajemen inovasi sebagai dampak globalisasi di berbagai bidang kehidupan. MBO ini.

\section{c. Manajemen Berdasarkan Informasi (MBI)}

Menurut Shrode D. Voich menjelaskan bahwa informasi adalah sumber dasar bagi organisasi dan esensial agar operasionalisasi dan manajemen berfungsi secara efektif. Informasi yang dibutuhkan oleh manajer berkenaan dengan konsumen, pemasok dan lingkungan untuk menentukan pilihan dan 
perencanaan. Berkenaan dengan hal itu, Gordon B. Darvis (1974) mengartikan sistem informasi manajemen sebagai sebuah sistem manusia/mesin yang terpadu untuk menyajikan informasi guna mendukung fungsi operasi, manajemen dan pengambilan keputusan dalam sebuah organisasi. Dengan perkataan lain $\mathrm{MBI}$ merupakan keseluruhan jaringan informasi yang ditujukan kepada pembuatan keterangan-keterangan bagi manajer yang berfungsi untuk pengambilan keputusan. Informasi itu sendiri merupakan data yang telah diolah, dianalisis melalui suatu cara sehingga menjadi berarti. Sedangkan data adalah fakta atau fenomena yang belum dianalisis, seperti jumlah, angka, nama, lambang yang menggambarkan suatu objek, ide, kondisi, dan situasi (Fatah, 2009).

\section{Prinsip-Prinsip Manajemen Pendidikan}

Douglas merumuskan prinsip-prinsip manajemen pendidikan sebagai berikut : 1) memprioritaskan tujuan diatas kepentingan pribadi dan kepentingan mekanisme kerja; 2) mengkoordinasi wewenang dan tanggung jawab; 3) memberikan tanggung jawab pada personil sekolah hendaknya sesuai dengan sifat-sifat dan kemampuannya; 4) mengenal secara baik faktor-faktor psikologis manusia; 5) relativitas nilai-nilai (Pidarta, 2004). Prinsip-prinsip diatas memiliki esensi bahwa manajemen dalam ilmu dan praktiknya harus memperhatikan tujuan, orang-orang, tugas-tugas, dan nilai-nilai. Tujuan dirumuskan dengan tepat sesuai dengan arah organisasi, tuntutan zaman, dan nilai-nilai yang berlaku. Tujuan suatu organisasi dapat dijabarkan dalam bentuk visi, misi dan sasaran-sasarannya. Ketiga bentuk tujuan itu harus dirumuskan dalam satu kekuatan tim yang memiliki komitmen terhadap kemajuan dan masa depan organisasi.

Untuk seorang manajer, suatu teori tentang manajemen sangat berfungsi dalam memecahkan masalah-masalah yang timbul. Oleh karena itu, falsafah, asumsi, prinsip-prinsip dan teori tentang manajemen merupakan landasan manajerial yang harus dipahami dan dihayati oleh manajer. Keterkaitan cara pandang tentang manajemen, falsafah, asumsi, dan prinsip, serta teori-teori dijadikan dasar kegiatan manajerial.

\section{SIMPULAN}

Teori di bidang manajemen secara spesifik berguna untuk menentukan cara atau strategi agar sebuah organisasi dapat dikelola secara efektif dan efisien. Dengan teori dapat ditemukan cara yang tepat untuk mengelola sumber daya, cara termudah 
mengerjakan pekerjaan, dana termutah membiayai pekerjaan, waktu tersingkat melaksanakan pekerjaan, alat yang tepat untuk memperingan beban dan memperpendek jarak melaksanakan pekerjaan. Teori manajemen secara filosofis mendasari sebuah kepemimpinan agar mampu membangun kehidupan organisasi dengan mengembangkan budaya yang disebut nilai-nilai ekselensi atau keunggulan (value of exellence). Organisasi manajemen memerlukan pimpinan atau manajer yang mengerti benar perkembangan teori-teori manajemen agar manajer tersebut memiliki visi yang bijaksana dan mampu mengilhami staf atau pekerja dan semua komunitas organisasi. Teori-teori manajemen pada perkembangannya dapat dikelompokkan menjadi periode teori manajemen kuno, teori manajemen klasik, teori manajemen ilmiah dan teori manajemen organisasi.

Falsafah manajemen menjelaskan tentang cara pemahaman falsafah manajemen secara sistemik dapat menjadi alat untuk meramalkan dan mengendalikan peristiwa atau gejala yang muncul dalam praktik manajerial. Sedangkan untuk proses manajemen berguna untuk menentukan tujuan dan sasaran yang ingin dicapai, untuk menentukan strategi dan rencana kerja menjadi program kerja, pelaksanaan kegiatan operasional, pelaksanaan penilaian, pelaksanaan pengorganisasian. Untuk bidang kajian manejemen pendidikan, manajemen pendidikan sebagai suatu proses perencanaan, pengorganisasian, pelaksanaan dan pengawasan dalam mengelola sumber daya untuk mencapai tujuan yang efektif dan efisien dalam bidang pendidikan.

Prinsip manajemen bersifat luwes (fleksibel) dan tidak mutlak, tetapi harus diterapkan sesuai dengan perubahan dan kondisi-kondisi yang khusus pula karena jika manajemen tidak dijalankan sesuai dengan prinsip-prinsip manajemen, maka besar sekali kemungkinannya akan timbul mismanagement (salah urus). Oleh karena itu, untuk mengatasi hal-hal yang tidak diharapkan maka prinsip-prinsip dasar sangatlah penting dalam praktik manajemen. Dalam kaitannya dengan prinsip dasar manajemen, Fayol mengemukakan 14 prinsip dasar manajemen yang dijadikan patokan dalam praktek manajerial dalam melakukan manajemen yang berorientasi kepada sasaran (MBS), Managemen Berdasarkan Orang (MBO), dan Managemen Berdasarkan Informasi (MBI). Semuanya itu dimaksudkan untuk meningkatkan efektivitas, efisiensi, dan produktivitas kerja.

\section{DAFTAR PUSTAKA}

Abdurrahman Saleh Abdullah. (1994). Teori-teori Pendidikan Berdasarkan Al Quran. 
Jakarta: Rineka Cipta.

Arikunto, S., \& Lia Yuliana. (2012). Manajemen Pendidikan. Yogyakarta: Aditya Media. Danim, S., \& Suparno. (2009). Manajemen dan Kepemimpinan Transformasional Kekepalasekolahan, Visi dan Strategi Sukses Era Teknologi, Situasi Krisis, dan Internasionalisasi Pendidikan. Jakarta: Rineka Cipta.

Darmono. (2001). Manajemen dan Tata Kerja Perpustakaan Sekolah. Jakarta: Gramedia Widiasarana Indonesia.

Duhou, I. A. (2004). School Based Management. Jakarta: Kencana.

Fatah, N. (2009). Landasan Manajemen Pendidikan. Bandung: RosdaKarya.

Gomes, F. C. (2003). Manajemen Sumber Daya Manusia. Yoyakarta: PT. Andi Offset. Hadari Nawawi. (2005). Manajemen Strategik, Organisasi Non Profit Bidang Pemerintahan dengan Ilustrasi Bidang Pendidikan. Yogyakarta: Gajah Mada University Press.

Hamalik, O. (2012). Manajemen Pengembangan Kurikulum. Bandung: Remaja Rosdakarya.

Imam al-Mawardi. (1955). Adab al-Dunya wa al-Din. Cairo: Al-Matba`ah al-Amiroh.

Luwis R. Benston. (1972). Supervision and Management. New York: McGraw Hill Book Company.

M, H. S. (2003). Kapita Selekta Manajemen Pendidikan. Bandung: CV. Alfabeta.

Malayu S.P. Hasibuan. (2008). Manajemen Sumber Daya Manusia. Jakarta: Bumi Aksara.

Mamduh M. Hanafi. (1997). Manajemen. Yogyakarta: Unit Penerbitan dan Percetakan Akademi Manajemen Perusahaan YKPN.

Muhammad Ja'far Nashir. (2006). Sejarah Perkembangan Manajemen Pendidikan di Indonesia. Magelang: Universitas Muhammadiyah Magelang Press.

Mulyasa, E. (2013). Pengembangan dan Implementasi Kurikulum. Bandung: PT. Remaja Rosdakarya.

Murtadha Muthahhari. (2010). Pengantar Epistemologi Islam: Sebuah Pemetaan dan Kritik Epistemologi Islam atas Paradigma Pengetahuan IImiah dan Relevansi Pandangan Dunia. Jakarta: Sadhra Press.

Mustaqim. (n.d.). Psikologi Pendidikan. Yogyakarta: Pustaka Pelajar.

Pidarta, M. (2004). Manajemen Pendidikan Indonesia. Jakarta: PT. Rineka Cipta.

Purwanto, N. (1991). Administrasi dan Supervisi Pendidikan. Jakarta: PT. Remaja Rosdakarya. 
Siagian, S. P. (2008). Manajemen Sumber Daya Manusia. Jakarta: Bumi Aksara.

Sondang P. Siagian. (1985). Filsafat Administrasi. Jakarta: Gunung Agung.

Sukamto Reksohadiprodjo. (1996). Dasar-Dasar Manajemen. Yogyakarta: BPFE.

Sulistyorini. (2009). Manajemen Pendidikan Islam. Yogyakarta: Teras.

Suparman Syukur. (2007). Etika Religius. Yogyakarta: Pustaka Pelajar.

Tunggal, A. W. (1993). Manajemen Suatu Pengantar. Jakarta: Rineka Cipta.

William J. Bailey. (1991). School-Site Management Applied. Lancaster-Basel: Technomic Publishing CO.INC.

Winardi, J. (2004). Manajemen Perilaku Organisasi. Jakarta: Kencana.

Winfred F. Hill. (2009). Theories of Learning. Bandung: Nusa Media. 